\title{
Audit Layanan SKA (Surat Keterangan Asal) Untuk Barang Ekspor Menggunakan Framework COBIT 5
}

\author{
Anak Agung Ngurah Agung AdityaWinata, I Made Sukarsa, Ni Kadek Dwi Rusjayanthi \\ Program Studi Teknologi Informasi, Fakultas Teknik, Universitas Udayana \\ Bukit Jimbaran, Bali, Indonesia-803611 \\ e-mail: adityangurah26@gmail.com, sukarsa@it.unud.ac.id, dwi.rusjayanthi@unud.ac.id
}

\begin{abstract}
Abstrak
Kinerja ekspor sangat dipengaruhi oleh kualitas dan kuantitas produk yang diekspor sehingga harus didukung oleh fasilitas negara yaitu Surat Keterangan Asal. SKA merupakan salah satu fasilitas yang disediakan oleh negara berupa dokumen ekspor untuk mendapatkan referensi atau non referensi untuk ekspor. Audit sangat penting untuk mendukung tata kelola teknologi informasi terkait kecepatan dan ketepatan hasil sehingga audit Surat Keterangan Asal (SKA) dilakukan menggunakan COBIT 5 pada penelitian ini, mengingat pentingnya fungsi SKA terhadap kinerja ekspor. Hasil audit yang diperoleh yaitu beberapa titik kritis yang mengacu pada pelayanan kinerja ekspor yaitu belum optimalnya pelayanan penerbitan Surat Keterangan Asal (SKA) dan dilakukan pemetaan dari titik kritis sampai analisa tingkat kematangan maka dapat disimpulkan lima proses TI yaitu EDM05, APO07, DSS02, DSS03 dan DSS06 untuk rekomendasi serta saran menggunakan standar ISO/IEC 15504:2 2003 serta COSO Internal Control Framework.
\end{abstract}

Kata Kunci: Fasilitas Kinerja Ekspor, COBIT 5, Capabiltiy Level, Proses TI, ISO/IEC 15504:2003, COSO Internal Control Framework

\begin{abstract}
Export performance is strongly influenced by the quality and quantity of products exported so that it must be supported by state facilities, namely Certificate of Origin. Certificate of Origin (COO) is one of the facilities provided by the state in the form of export documents to obtain references or non-references for exports. The audit is very important to support information technology governance related to the speed and accuracy of the results so that the audit of Certificate of Origin (COO) is carried out using COBIT 5 in this study, given the importance of the function of SKA on export performance. The audit results obtained are several critical points that refer to the export performance service, namely the not yet optimal service for issuing Certificate of Origin (COO) and mapping from critical point to maturity level analysis. DSS06 for recommendations and suggestions using the ISO / IEC 15504: 22003 standards and the COSO Internal Control Framework.
\end{abstract}

Keywords: Export Performance Facilities, COBIT 5, Capability Level, IT Process, ISO/IEC 15504: 2003, COSO Internal Control Framework

\section{Pendahuluan}

Komoditi non migas merupakan komoditi ekspor utama Bali yang memberikan peran penting bagi perekonomian nasional khususnya Bali, peran perdagangan luar negeri dalam mendukung perekonomian tidak bisa diabaikan begitu saja, pencapaian kinerja ekspor non migas tidak terlepas dari berbagai faktor yang mempengaruhi kinerja ekspor [1]. Fasilitas yang disediakan oleh pemerintah untuk mendukung kinerja ekspor bagi pelaku usaha berupa kemudahan referensi atau non referensi dengan dokumen Surat Keterangan Asal (SKA). Kinerja pelayanan penerbitan Surat Keterangan Asal (SKA) untuk eksportir mendapatkan pelayanan yang kurang dari pihak pegawai IPSKA Bali, oleh karena itu perlu dilakukan audit layanan Surat Keterangan Asal (SKA) sehingga dapat diketahui penyebab kurangnya pelayanan SKA bagi eksportir. Audit sangat penting untuk mendukung tata kelola teknologi informasi terkait kecepatan dan ketepatan hasil sehingga audit Surat Keterangan Asal (SKA) dilakukan menggunakan COBIT 5 pada penelitian ini. COBIT 5 menyediakan analisis untuk membantu organisasi atau perusahaan dalam meningkatkan pencapaian tujuan dan aspek 
manajemen tata kelola TI. COBIT 5 merancang model agar dapat diterima secara global untuk membantu analisis termasuk memaksimalkan tingkat kematangan dalam mengontrol $\mathrm{TI}$ di seluruh organisasi atau perusahaan [2].

Audit dilakukan pada instansi IPSKA Bali yang berbeda dalam penelitian saat ini yaitu masih menggunakan framework COBIT 5 sebagai langkah untuk meningkatkan waktu pelayanan penerbitan Surat Keterangan Asal (SKA). Audit layanan instansi pemerintah menggunakan framework COBIT 5 diantaranya adalah "Information Technology Governance Archetype in an Indonesian University"oleh Riza Afrizza Islami yang melakukan audit teknologi informasi sebagai layanan, struktur dan kontrol dalam keselarasan tata kelola instansi pemerintah dengan tujuan bisnis untuk universitas $A B C$, bertujuan untuk menerapkan pola dasar dalam mencapai keselarasan tujuan bisnis meliputi prinsip arsitektur, infrastruktur, kebutuhan aplikasi bisnis dan investasi dengan menggunakan kerangka kerja COBIT 4.1 sebagai acuan penelitian [3]. "Internal Control Improvement for Creating Good Governance" oleh I Wayan Prasada Bharaditya merupakan penelitian yang membahas tentang audit terhadap koperasi instansi pemerintah serta membangun kontrol internal menggunakan COBIT 5 , COSO dan ITIL, bertujuan untuk membangun kontrol yang dapat menyelesaikan masalah internal yang terjadi di setiap proses [4]. Penelitian audit layanan Surat Keterangan Asal untuk Barang Ekspor dimaksudkan untuk melakukan audit pada Institusi Penerbit Surat Keterangan Asal (IPSKA BALI) dengan mengukur tingkat kapabilitas layanan surat keterangan asal dan dapat memperbaiki maturity GAP. Penggunaan COBIT 5 merupakan kerangka kerja yang dapat digunakan untuk melakukan penilaian tingkat kematangan dengan menyusun pendapat, simpulan, saran dan rekomendasi bagi instansi pemerintah seperti halnya penelitian sebelumnya yang nantinya dapat digunakan sebagai tinjauan untuk melakukan perbaikan pengelolaan teknologi informasi yang berfokus pada layanan penerbitan Surat Keterangan Asal.

\section{Metodologi Penelitian}

Metodologi penelitian merupakan langkah yang sudah ditetapkan dalam melakukan penelitian. Tujuan dari metodologi penelitian ini adalah agar proses penelitian yang dilakukan menjadi lebih teratur, sistematis, terkontrol dan terarah.

\subsection{Tahapan Proses Audit}

Tahapan proses audit layanan surat keterangan asal untuk barang ekspor menggunakan framework COBIT 5 dijabarkan pada Gambar 1. 


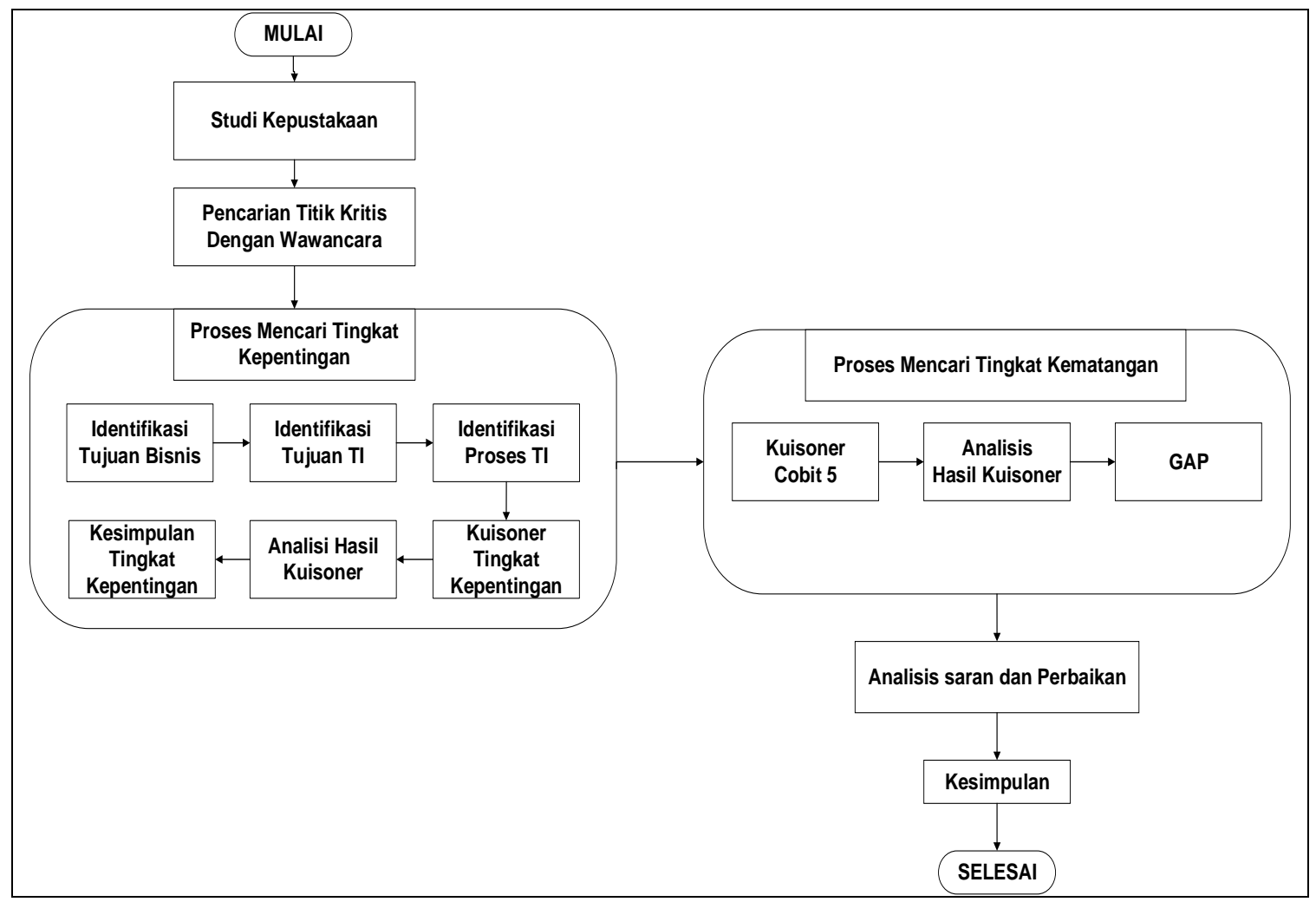

Gambar 1. Tahapan Proses Audit

Tahapan penelitian audit layanan surat keterangan asal untuk barang ekspor yaitu penentuan studi kepustakaan, pencarian titik kritis melalui wawancara narusumber pegawai maupun pelaku usaha, pencarian tingkat kepentingan, pencarian tingkat kematangan pemberian saran dan perbaikan, serta kesimpulan. Tahapan Proses audit menggunakan Framework COBIT 5 terkait dengan proses bisnis layanan surat keterangan asal untuk barang ekspor digunakan sebagai acuan dalam penyusunan kuesioner. Hasil kuesioner digunakan sebagai sumber data untuk mengukur tingkat capability pada layanan surat keterangan asal untuk barang ekspor dan menentukan target tingkat capability serta menentukan GAP untuk memberikan rekomendasi perbaikan pada layanan instnasi pemerintah.

\subsection{Metode Pengumpulan Data}

Metode pengumpulan data penelitian audit layanan SKA (Surat Keterangan Asal) dilakukan dengan menggunakan 3 metode pengumpulan data yaitu [5].

a. Wawancara (Interview) dilakukan dengan menggunakan cara tanya jawab yang sistematis serta belandaskan kepada tujuan penelitian.

b. Angket (Quistionnare) mendefinisikan pembuatan kuesioner tingkat kepentingan yang berisi pertanyaan titik masalah layanan SKA yang mengacu dengan standar Proses TI COBIT 5 serta kuesioner capability level yang mengacu pada dokumen PAM using COBIT 5 Toolkit Self Assement.

c. Observasi dilakukan untuk melakukan pengamatan terhadap kondisi eksisting (kondisi yang sudah ada) objek penelitian yang diaudit serta untuk menyesuaikan hasil kuesioner serta digunakan sebagai acuan dalam penentuan pembuatan rekomendasi dan saran pada layanan instansi pemerintah. Observasi dilanjutkan dengan melakukan penyusunan kuesioner tingkat kepentingan serta penyusunan kuesioner capability level yang dapat mendefinisikan domain proses TI. Contoh penilaian tingkat kepentingan dan capability Level terdapat pada Tabel 1 dan 2. 
Tabel 1. Penilaian Tingkat Kepentingan

\begin{tabular}{|c|c|c|c|c|c|c|c|}
\hline \multirow{2}{*}{ No. } & Titik Masalah & $\begin{array}{c}\text { Bobot } \\
=1\end{array}$ & $\begin{array}{c}\text { Bobot } \\
=2\end{array}$ & $\begin{array}{c}\text { Bobot } \\
=3\end{array}$ & $\begin{array}{c}\text { Bobot } \\
=4\end{array}$ & $\begin{array}{c}\text { Bobot } \\
=5\end{array}$ & $\begin{array}{c}\text { Total } \\
=\left(\mathrm{N}^{*} \mathrm{~B}\right)\end{array}$ \\
\hline 1. & $\begin{array}{l}\text { Proses tata cara pengurusan } \\
\text { SKA yang tergolong rumit }\end{array}$ & & & & & & \\
\hline
\end{tabular}

Tabel penilaian tingkat kepentingan merupakan penetapan skor nilai dari setiap bobot pertanyaan yang akan dijawab oleh responden. Tabel penilaian tingkat kepentingan merupakan tabel acuan untuk menghitung penilaian pada draft kuesioner tingkat kepentingan.

Tabel 2. Rating Skala Penilaian Capability Level

\begin{tabular}{|c|c|}
\hline Nilai & Status \\
\hline $0 \%-15 \%$ & Not Achieved \\
\hline $15 \%-50 \%$ & Partially Achieved \\
\hline $50 \%-85 \%$ & Largely achieved \\
\hline $85 \%-100 \%$ & Fully achieved \\
\hline
\end{tabular}

Tabel rangkuman penjelasan rating skala penilaian capability level pada COBIT 5 yang berisi penjelasan status penilaian kusioner capability level berdasarkan COBIT 5 yaitu Not achieved, Partially achieved, Largely achieved, Fully achieved yang mengacu pada dokumen PAM using COBIT 5 Toolkit, hal. 1. Tabel rating skala capability level pada COBIT 5 merupakan tabel acuan untuk menghitung skala penilaian pada draft kuesioner capability level [6].

\section{Kajian Pustaka}

\subsection{Audit Teknologi Informasi}

Audit Teknologi Informasi merupakan proses pengumpulan dan penilain untuk menentukan bukti bahwa sistem komputer dapat mengamankan aset, memelihara integritas data serta dapat mendorong pencapain tujuan peningkatan tata kelola TI (IT Governance) secara efektif dengan menerapkan SLDC (System Development Life Cycle). Audit perlu dilakukan untuk mengetahui sistem pengelolaan teknologi informasi sudah dilengkapi dengan kontrol yang memadai [7]. Kontrol dan audit TI memiliki faktor-faktor penting adalah sebagai berikut.

a. Meningkatkan keamanan sistem dan pengelolaan aset secara sistematis, pelatihan sumber daya pegawai perushaan secara terarah, kontrol pola karier personil yang baik.

b. Meningkatkan kerahasian sistem informasi perushaan agar terjaga privacy para pengguna.

c. Meningkatkan pengendalian evolusi penggunaan komputer.

d. Meningkatkan hasil pengembilan keputusuan berdasarkan proses sistem komputerisasi.

\subsection{COBIT 5}

COBIT (Control Objectives for Information and Related Technology) merupakan sebuah kerangka kerja tata kelola TI dalam mendukung dan menjembatani kesenjangan diantara control, masalah teknis dan resiko bisnis. COBIT 5 memiliki beberapa prinsip yaitu Meeting Stakeholder Need, Covering the Enterprise End-to-end, Applying a Single Integrated Framework, Enabling a Holistic Approach, Separating Governance From Management [8].

\subsection{Pengukuran Capability Model COBIT 5}

Pengukuran capability model COBIT 5 merupakan tahapan untuk mengukur tingkat kemampuan sebuah organisasi atau perusahaan metode untuk mengukur level pengembangan manajemen proses, yang berarti adalah mengukur sejauh mana tingkat kapabilitas manajemen tersebut. Pengukuran capability model COBIT 5 memiliki tingkat yang dianggap penting yaitu [10]:

Incomplete Process, Level 1 Performed Process, Level 2 Managed Process, Level 3 Established Proces, Level 4 Predictable Process, Level 5 Optimising [6]. 


\section{4 coso Internal Control Framework}

COSO Internal Control Framework merupakan kerangka kerja yang dibuat untuk penilaian berdasarkan pengendalian internal yang berkelanjutan dan mengambil tindakakantindakan dalam rangka menjaga akutabilitas seperti kebijkan prosedur, keamanan sistem dan pelayanan, kualitas informasi dan efektivitas komunikasi [4].

\section{Hasil dan Pembahasan}

\subsection{Identifikasi Tujuan Bisnis}

Identifikasi tujuan bisnis merupakan tahap pertama dalam melakukan proses audit untuk menentukan proses TI. Identifikasi Tujuan bisnis menurut framework COBIT 5 memiliki 4 perspektif yaitu perspektif keuangan, pelanggan, internal serta pembelejaran dan pertumbuhan yang berjumlah 17 tujuan bisnis. Proses identifikasi tujuan bisnis dilakukan dengan memetakan titik kritis terhadap tujuan bisnis menurut framework COBIT 5. Hasil pemetaan keterkaitan titik kritis dengan tujuan bisnis berdasarkan framework COBIT 5 seperti pada Tabel 3.

Tabel 3. Pemetaan Titik Kritis dengan Tujuan Bisnis COBIT 5

\begin{tabular}{|c|c|c|c|}
\hline No. & Titik Kritis & No. & Tujuan Bisnis \\
\hline \multirow[t]{2}{*}{1.} & \multirow{2}{*}{$\begin{array}{l}\text { pelayanan surat keterangan asal menjadi } \\
\text { terhambat karena kekurangan dokumen } \\
\text { pendukung }\end{array}$} & 7. & $\begin{array}{l}\text { Ketersediaan layanan bisnis yang } \\
\text { berkelanjutan. }\end{array}$ \\
\hline & & 9. & $\begin{array}{l}\text { Strategi pengambilan keputusan } \\
\text { berdlasarkan informasi yang ada. }\end{array}$ \\
\hline \multirow[t]{2}{*}{2.} & \multirow{2}{*}{$\begin{array}{l}\text { bimbingan teknis bagi pegawai untuk } \\
\text { meningkatkan kualitas layanan dan } \\
\text { perlunya penambahan tenaga oprasional }\end{array}$} & 14. & Staff dan operasional yang produktif. \\
\hline & & 16. & $\begin{array}{l}\text { Pegawai yang terampil dan } \\
\text { termotivasi }\end{array}$ \\
\hline \multirow[t]{2}{*}{3.} & \multirow[t]{2}{*}{$\begin{array}{l}\text { Sistem maupun infrastruktur perlu } \\
\text { ditingkatkan. }\end{array}$} & 8. & $\begin{array}{l}\text { Respon yang cepat terhadap } \\
\text { lingkungan bisnis yang berubah. }\end{array}$ \\
\hline & & 9. & $\begin{array}{l}\text { Strategi pengambilan keputusan } \\
\text { berdasarkan informasi yang ada. }\end{array}$ \\
\hline 4. & $\begin{array}{l}\text { Belum adanya standarisasi penentuan } \\
\text { harga barang. }\end{array}$ & 7. & $\begin{array}{l}\text { Ketersediaan layanan bisnis yang } \\
\text { berkelanjutan. }\end{array}$ \\
\hline \multirow[t]{2}{*}{5.} & \multirow[t]{2}{*}{$\begin{array}{l}\text { eksportir mengangap rumit pengurusan } \\
\text { SKA. }\end{array}$} & 8. & $\begin{array}{l}\text { Respon yang cepat terhadap } \\
\text { lingkungan bisnis yang berubah }\end{array}$ \\
\hline & & 9. & $\begin{array}{l}\text { Strategi pengambilan keputusan } \\
\text { berdasarkan informasi yang ada. }\end{array}$ \\
\hline
\end{tabular}

\subsection{Identifikasi Tujuan TI}

Identifikasi Tujuan TI menurut framework COBIT 5 memiliki 4 perspektif yaitu perspektif keuangan, pelanggan, internal serta pembelejaran dan pertumbuhan yang berjumlah 17 tujuan TI. Identifikasi tujuan TI merupakan tahap kedua yang dilakukan sesudah mendapatkan hasil pemetaan titik kritis dan tujuan bisnis menurut framework COBIT 5. Hasil pemetaan tujuan bisnis dengan tujuan TI berdasarkan framework COBIT 5 seperti pada Tabel 4.

Tabel 4. Pemetaan Tujuan Bisnis dengan Tujuan TI

\begin{tabular}{|c|c|c|c|}
\hline No. & Tujuan Bisnis & No. & Tujuan TI \\
\hline 7 & $\begin{array}{l}\text { Ketersediaan layanan bisnis yang } \\
\text { berkelanjutan. }\end{array}$ & 14 & $\begin{array}{l}\text { Ketersediaan informasi yang } \\
\text { dipercaya dan bermanfaat } \\
\text { pengambilan keputusan. }\end{array}$ \\
\hline \multirow[t]{3}{*}{8} & \multirow[t]{3}{*}{$\begin{array}{l}\text { Respon yang cepat terhadap } \\
\text { lingkungan bisnis yang berubah. }\end{array}$} & 7 & $\begin{array}{l}\text { Pengiriman layanan } \mathrm{TI} \text { yang sesuai } \\
\text { dengan kebutuhan bisnis. }\end{array}$ \\
\hline & & 9 & Ketangkasan TI. \\
\hline & & 1 & Penyelarasan TI dengan strategi bisnis \\
\hline 9 & $\begin{array}{l}\text { Strategi pengambilan keputusan } \\
\text { berdasarkan informasi yang ada. }\end{array}$ & 14 & $\begin{array}{l}\text { Ketersediaan informasi yang } \\
\text { dipercaya dap bermanfaat } \\
\text { pengambilan keputusan. }\end{array}$ \\
\hline \multirow[t]{2}{*}{14} & \multirow[t]{2}{*}{ Staff dan operasional yang produktif. } & 8 & $\begin{array}{l}\text { Penggunaan aplikasi, informasi, dan } \\
\text { solusi teknologi yang memadai. }\end{array}$ \\
\hline & & 16 & Personil TI yang kompeten serta memiliki \\
\hline
\end{tabular}




\begin{tabular}{|c|lr|r|l|}
\hline 16 & $\begin{array}{l}\text { Pegawai yang terampil dan } \\
\text { termotivasi. }\end{array}$ & 16 & $\begin{array}{l}\text { Petivasi terhadap bisnis yang ada. } \\
\text { motivasi terhadap bisnis yang ada. }\end{array}$ \\
\cline { 3 - 4 } & 17 & $\begin{array}{l}\text { Pengetahuan, keahlian, dan inisiatif } \\
\text { untuk inovasi bisnis }\end{array}$ \\
\hline
\end{tabular}

\subsection{Identifikasi Proses TI (IT Process)}

Identifikasi proses TI menurut COBIT 5 berjumlah 37 proses TI. Tahap pemetaan tujuan TI dengan proses TI merupakan tahap ketiga yang dilakukan untuk menentukan domain proses TI. Hasil pemetaan tujuan TI dengan proses TI berdasarkan framework COBIT 5 seperti pada Tabel 5.

Tabel 5. Pemetaan Tujuan TI dengan Proses TI

\begin{tabular}{|c|c|c|c|c|c|c|}
\hline \multirow[t]{2}{*}{ No. } & \multirow[t]{2}{*}{ Tujuan TI } & \multicolumn{5}{|c|}{ Proses TI } \\
\hline & & EDM & APO & BAI & DSS & MEA \\
\hline 7 & $\begin{array}{l}\text { Pengiriman layanan } \mathrm{TI} \text { yang sesuai dengan } \\
\text { kebutuhan bisnis }\end{array}$ & 2 & $4,9,11$ & - & 2,3 & 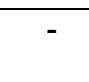 \\
\hline 8 & $\begin{array}{l}\text { Penggunaan aplikasi, informasi, dan solusi } \\
\text { teknologi yang memadai }\end{array}$ & 2 & $4,9,11$ & - & 2,3 & - \\
\hline 9 & Ketangkasan TI & - & 4,9 & - & $1,2,3$ & - \\
\hline 14 & $\begin{array}{l}\text { Ketersediaan informasi yang dapat dipercaya } \\
\text { dan bermanfaat bagi pengambilan keputusan }\end{array}$ & 5 & - & - & 6 & - \\
\hline 16 & $\begin{array}{l}\text { Personil TI yang kompeten serta memiliki } \\
\text { motivasi terhadap bisnis yang ada }\end{array}$ & - & 7 & 4,8 & $1,2,3$ & - \\
\hline 17 & $\begin{array}{l}\text { Pengetahuan, keahlian, dan inisiatif untuk } \\
\text { inovasi bisnis }\end{array}$ & - & 4,7 & 8 & 2,3 & 1 \\
\hline
\end{tabular}

\subsection{Penentuan RACI Chart}

Penentuan RACl chart dilakukan untuk mengetahui tugas pegawai yang berwenang dalam proses bisnis pelayanan surat keterangan asal untuk barang ekspor. Hasil penentuan $\mathrm{RACl}$ chart mengacu pada standard operation procedure pegawai bidang Perdagangan Luar Negeri seperti pada Tabel 6.

Tabel 6. RACI Chart Bidang Perdagangan Luar Negeri

\begin{tabular}{|l|c|c|c|c|c|c|}
\hline \multirow{2}{*}{ Aktivitas } & \multicolumn{5}{|c|}{ Entitas } \\
\cline { 2 - 7 } & $\mathbf{1}$ & $\mathbf{2}$ & $\mathbf{3}$ & $\mathbf{4}$ & $\mathbf{5}$ \\
\cline { 2 - 7 } & \multicolumn{5}{|c|}{ Komponen } \\
\hline $\begin{array}{l}\text { Memastikan kelengkapan dokumen dengan melakukan } \\
\text { pemeriksaan atas dokumen eksportir. }\end{array}$ & $\mathrm{A}$ & $\mathrm{R}$ & $\mathrm{R}$ & $\mathrm{R}$ & $\mathrm{C}$ \\
\hline $\begin{array}{l}\text { Melakukan pembinaan pegawai dan eskportir yang } \\
\text { berorientasi ekspor. }\end{array}$ & $\mathrm{A}$ & $\mathrm{C}$ & $\mathrm{R}$ & $\mathrm{R}$ & $\mathrm{C}$ \\
\hline $\begin{array}{l}\text { Mengidentifikasi dan membuat tindakan perencanaan dalam } \\
\text { hal pemeliharaan sarana prasarana. }\end{array}$ & $\mathrm{A}$ & $\mathrm{C}$ & $\mathrm{I}$ & $\mathrm{I}$ & $\mathrm{C}$ \\
\hline $\begin{array}{l}\text { Memastikan pihak eksportir sudah mengacu pada peraturan } \\
\text { mentri perdagangan no 12 tahun 2012 dalam hal } \\
\text { standarisasi harga barang. }\end{array}$ & $\mathrm{A}$ & $\mathrm{C}$ & $\mathrm{C}$ & $\mathrm{C}$ & $\mathrm{C}$ \\
\hline $\begin{array}{l}\text { Melakukan pembinaan pelaku usaha yang berorientasi } \\
\text { ekspor demi kelancaran penerbitan surat keterngan asal. }\end{array}$ & $\mathrm{A}$ & $\mathrm{C}$ & $\mathrm{C}$ & $\mathrm{C}$ & $\mathrm{C}$ \\
\hline
\end{tabular}

Penentuan RACI Chart telah disesuaikan dengan proses identifikasi tingkat kepentingan beradasarkan proses $\mathrm{TI}$ yang mengacu dari hasil pemetaan tujuan bisnis serta tujuaan $\mathrm{TI}$. Entitas RACl chart merupakan responden top level management untuk mengisi kuesioner tingkat kepentingan dan kuesioner capability level. Komponen RACl Chart yaitu responsible, accountable, consult dan inform. Entitas RACl chart terdiri dari 1) Kepala Bidang Perdagangan Luar Negeri, 2) Pejabat Penandatanganan Surat Keterangan Asal, 3) Kepala Seksi Pengembangan Ekspor, 4) Kepala Seksi Bina Pelaku Ekspor dan Impor, 5) Kepala seksi Fasilitasi Ekspor dan Impor. 


\subsection{Draft Kuesioner Tingkat Kepentingan}

Draft kuesioner tingkat kepentingan terdiri dari titik masalah yang terdapat pada layanan surat keterangan asal. Responden dapat memilih titik masalah berdasarkan kondisi yang ada pada Bidang Pengembangan Perdagangan Luar Negeri. Kuesioner tingkat kepentingan dapat mendefinisikan titik masalah yang sudah dikaitkan dengan standar proses TI COBIT 5. Contoh kuesioner tingkat kepentingan terdapat pada Tabel 7.

Tabel 7. Contoh Kuesioner Tingkat Kepentingan

\begin{tabular}{|c|l|l|l|l|l|l|}
\hline \multirow{2}{*}{ No. } & \multicolumn{1}{|c|}{ Ttitk Masalah } & \multicolumn{3}{|c|}{ Skor Tingkat Kepentingan } \\
\cline { 3 - 6 } & & STP & TP & \multicolumn{1}{|c|}{ CP } & P & SP \\
\cline { 3 - 6 } & \multicolumn{5}{|c|}{ Bobot } \\
\cline { 3 - 6 } & & $\mathbf{1}$ & $\mathbf{2}$ & $\mathbf{3}$ & $\mathbf{4}$ & $\mathbf{5}$ \\
\hline 1. & $\begin{array}{l}\text { Pelayanan surat keterangan asal menjadi terlambat } \\
\text { karena kriteria berkas dokumen yang dipersyaratkan } \\
\text { tidak lengkap. }\end{array}$ & & & & & \\
\hline 2. & Standarisasi harga satuan barang belum ada. & & & & & \\
\hline 3. & $\begin{array}{l}\text { Bimbingan teknis bagi pegawai untuk meningkatkan } \\
\text { kualitas layanan dalam mengoprasikan aplikasi e-SKA. }\end{array}$ & & & & & \\
\hline 4. & $\begin{array}{l}\text { Tingkat kesadaran eksportir terhadap pentingnya } \\
\text { pengumpulan arsip masih kurang. }\end{array}$ & & & & \\
\hline 5. & $\begin{array}{l}\text { Pembinaan kepada pegawai dan pelaku usaha untuk } \\
\text { pelaksanaan pelayanan surat keterangan asal untuk } \\
\text { barang ekspor masih kurang. }\end{array}$ & & & & & \\
\hline 6. & Sarana Komputer yang terbatas & & & & & \\
\hline 7. & $\begin{array}{l}\text { Terhambatnya pengoprasian aplikasi e-SKA karena } \\
\text { koneksi jarngan yang terputus antar server dengan } \\
\text { computer client. }\end{array}$ & & & & \\
\hline 8. & $\begin{array}{l}\text { Proses tata cara pengurusan surat keterangan asal } \\
\text { yang tergolong rumit. }\end{array}$ & & & & & \\
\hline 9. & $\begin{array}{l}\text { Respon pelayanan melalui via e-mail dan telelphone } \\
\text { belum optimal dari pihak pegawai. }\end{array}$ & & & & & \\
\hline 10. & $\begin{array}{l}\text { Penambahan tenaga oprasional dalam memperbaiki } \\
\text { sarana prasarana pengolahan data ekspor. }\end{array}$ & & & & \\
\hline 11. & $\begin{array}{l}\text { Petugas form sering mengalami keterlambatan } \\
\text { sehingga pelayanan menjadi terhambat. }\end{array}$ & & & & \\
\hline
\end{tabular}

Kuesioner tingkat kepentingan memiliki 5 penilaian yaitu sangat tidak penting, tidak penting, cukup penting, penting dan sangat penting. Kuesioner menghasilkan 5 domain proses TI tertinggi. Hasil penentuan domain proses TI tertinggi terdapat pada Tabel 8.

Tabel 8: Domain Tingkat Kepentingan

\begin{tabular}{|c|l|}
\hline Domain & \multicolumn{1}{|c|}{ Penjelasan } \\
\hline EDM03 & Memastikan optimasi resiko \\
\hline EDM05 & Memastikan transparasi milik pemangku kepentingan \\
\hline APO07 & Mengelola sumber daya manusia \\
\hline APO09 & Mengelola perjanjian layanan \\
\hline APO12 & Mengelola resiko \\
\hline DSS02 & Mengelola permintaan layanan serta insiden \\
\hline DSS04 & Pengelolaan keberlanjutan \\
\hline DSS03 & Mengelola masalah \\
\hline DSS06 & Mengelola kontrol bisnis proses \\
\hline
\end{tabular}

Domain yang terpilih dalam pemetaan proses TI yaitu EDM05, APO07, DSS02, DSS03, DSS06 merupakan hasil akhir kuesioner tingkat kepentingan yang telah dikaitkan dengan standard operation procedure layanan surat keterangan asal [2]. 


\subsection{Draft Kuesioner Capability Level}

Draft kuesioner capability level berisikan titik masalah yang digunakan dalam pernyataan kuesioner, deskripsi domain proses TI dan pertanyaan yang akan dijawab oleh responden. Draft kuesioner capability level dapat mendefinisikan domain proses TI yang disesuaikan dengan dokumen PAM using COBIT 5 Toolkit Self Assement, hal. 12. Contoh kuesioner capability leve/ 3.2 proses EDM05 terdapat pada Tabel 9.

Tabel 9. Contoh Kuesioner Capability Level Proses EDM05

\begin{tabular}{|l|l|l|l|}
\hline \multirow{2}{*}{ No. } & \multirow{2}{*}{ Level } & $\begin{array}{l}\text { Titik Masalah ke-1 } \\
\text { Pelayanan Surat Keterangan Asal menjadi terhambat karena } \\
\text { tingkat kelangkapan dokumen yang sah masih rendah. }\end{array}$ & $\begin{array}{c}\text { Nilai } \\
\text { (0-100) }\end{array}$ \\
\cline { 3 - 4 } & $\begin{array}{l}\text { Proses : EDM05 } \\
\text { Memastikan bahwa kinerja perusahaan, pengukuran kesesuaian } \\
\text { dan pelaporan bersifat transparan, dengan para pemangku } \\
\text { kepentingan menyetujui tujuan, metrik dan tindakan perbaikan } \\
\text { yang diperlukan. }\end{array}$ & $\begin{array}{l}\text { a. Petugas Institusi Penerbit Surat Keterangan Asal (IPSKA) } \\
\text { menerima laporan peneyerahan pengumpulan dokumen } \\
\text { arsip Surat Keterangan Asal (SKA) oleh pihak eksportir. }\end{array}$ & \\
\hline 1. & 3.2 & & \\
\hline
\end{tabular}

Rancangan Draft kuesioner capability level terdiri dari titik masalah yang digunakan dalam pernyataan kuesioner, deskripsi domain proses $\mathrm{TI}$ dan nilai yang diisi oleh pihak responden.

\subsection{GAP, Perbaikan dan Rekomendasi Draft Kuesioner Capability Level}

GAP merupakan hasil perhitungan lima domain proses TI dengan current maturity level di bawah expected maturity level. Hasil GAP target level dari capability menurut pihak top management level serta selisih dari GAP terdapat pada Tabel 10.

Tabel 10 : GAP Capability Level Proses TI

\begin{tabular}{|c|c|c|c|}
\hline Proses TI & $\begin{array}{c}\text { Current Capability } \\
\text { (CC) }\end{array}$ & $\begin{array}{c}\text { Expected } \\
\text { Capability (EC) }\end{array}$ & $\begin{array}{c}\text { GAP } \\
\text { (EC - CC) }\end{array}$ \\
\hline EDM05 & 3 & 5 & 2 \\
\hline APO07 & 2 & 5 & 3 \\
\hline DSS02 & 3 & 5 & 2 \\
\hline DSS03 & 3 & 5 & 2 \\
\hline DSS06 & 2 & 5 & 3 \\
\hline
\end{tabular}

Rekomendasi perbaikan layanan surat keterangan asal untuk barang ekspor diarahkan menuju tingkat kematangan yang diharapkan yaitu tingkat kematangan 5-optimised, dari tingkat yang lebih rendah menuju satu tingkat kematangan di atasnya secara urut. Rekomendasi perbaikan layanan surat keterangan asal untuk barang ekspor diarahkan menuju tingkat kematangan yang diharapkan yaitu tingkat kematangan 5-optimised, dari tingkat yang lebih rendah menuju satu tingkat kematangan di atasnya secara urut. Kesenjangan dari capability level proses TI dapat diatasi dengan menggunakan pedoman dari COBIT 5, sehingga langkah selanjutnya menangani perbaikan terhadap layanan surat keterangan asal untuk menuju capability level yang diaharapkan. Contoh kajian Rekomendasi dan perbaikan domain proses terdapat pada Tabel 11.

Tabel 11: Kajian Rekomendasi Perbaikan Domain Proses

\begin{tabular}{|c|c|c|c|}
\hline Domain & Penjelasan & Rekomendasi Eksisting & Rekomendasi Tambahan \\
\hline EDM05 & $\begin{array}{l}\text { Belum Optimal } \\
\text { melakukan analisa } \\
\text { kekurangan berkas } \\
\text { dokumen SKA. }\end{array}$ & $\begin{array}{lr}\text { Melaksankan } & \text { pendataan } \\
\text { menggunakan } & \text { metode } \\
\text { cek list. } & \end{array}$ & $\begin{array}{l}\text { Membuat aplikasi SIPANDU } \\
\text { didahului dengan studi } \\
\text { kelayakan, penganggaran, } \\
\text { bimtek dan mensosialisasikan } \\
\text { aplikasi SIPANDU. }\end{array}$ \\
\hline
\end{tabular}




\begin{tabular}{|c|c|c|c|}
\hline & $\begin{array}{l}\text { Keterlambatan } \\
\text { pengumpulan arsip } \\
\text { SKA kepada } \\
\text { IPSKA. }\end{array}$ & $\begin{array}{lr}\text { Membuat } & \text { surat teguran } \\
\text { kepada } & \text { eksportir yang } \\
\text { belum } & \text { mengarsipkan } \\
\text { SKA. } & \\
\end{array}$ & $\begin{array}{l}\text { Membuat aplikasi KISKUAT } \\
\text { diawali dengan pengusulan } \\
\text { anggaran dan penyusunan tim } \\
\text { seleksi. }\end{array}$ \\
\hline \multirow[t]{3}{*}{ APO07 } & $\begin{array}{l}\text { Penggunaan } \\
\text { aplikasi SKA belum } \\
\text { sesuai dengan } \\
\text { tugas pokok dan } \\
\text { fungsi. }\end{array}$ & $\begin{array}{lr}\text { Mengadakan } & \text { pelatihan } \\
\text { SDM bagi } & \text { eksportir } \\
\text { dibawah tagungjawab } \\
\text { kepala seksi. }\end{array}$ & $\begin{array}{l}\text { Membuat aplikasi SIPOLA } \\
\text { dengan mengganggarkan } \\
\text { APBD dan menyusun petunjuk } \\
\text { teknis dan memberikan TOT. }\end{array}$ \\
\hline & $\begin{array}{l}\text { Belum } \\
\text { ditetapkannya SK } \\
\text { petugas IPSKA. }\end{array}$ & $\begin{array}{l}\text { Menetapkan petugas } \\
\text { IPSKA dan menysusun } \\
\text { penetapan kinerja. }\end{array}$ & $\begin{array}{l}\text { Membuat buku personal } \\
\text { kinerja setiap hari serta } \\
\text { menyiapkan petunjuk } \\
\text { pelaksanaan pengisian buku } \\
\text { personal kinerja. }\end{array}$ \\
\hline & $\begin{array}{l}\text { Kopetensi } \\
\text { pengoprasian } \\
\text { aplikasi e-SKA } \\
\text { belum dimiliki oleh } \\
\text { petugas IPSKA. }\end{array}$ & $\begin{array}{l}\text { Melakukan pelayanan } \\
\text { sesuai dengan SOP. }\end{array}$ & $\begin{array}{l}\text { Melakukan peningkatan } \\
\text { kopetensi setiap semester bagi } \\
\text { petugas IPSKA. }\end{array}$ \\
\hline DSS02 & $\begin{array}{l}\text { Terbatasnya } \\
\text { sarana komputer. }\end{array}$ & $\begin{array}{l}\text { Mengadakan } \\
\text { pemeliharaan terhadap } \\
\text { sarana prasarana. }\end{array}$ & $\begin{array}{l}\text { Segera mengadakan } \\
\text { pengadaan komputer melalui } \\
\text { APBD dengan menyusun } \\
\text { spesifikasi computer. }\end{array}$ \\
\hline \multirow[t]{3}{*}{ DSS03 } & $\begin{array}{lr}\text { Proses validasi } \\
\text { terhambat } \\
\text { disebabkan oleh } \\
\text { tidak tertibnya } \\
\text { eksportir dalam } \\
\text { melengkapi } \\
\text { dokumen. } \\
\end{array}$ & $\begin{array}{l}\text { Eksportir } \quad \text { melengkapi } \\
\text { dokumen untuk proses } \\
\text { validasi. }\end{array}$ & $\begin{array}{l}\text { Menerbitkan ID card dalam } \\
\text { pengurusan dokumen SKA. }\end{array}$ \\
\hline & $\begin{array}{l}\text { Penggunaan form } \\
\text { belum sesuai } \\
\text { dengan SOP }\end{array}$ & $\begin{array}{l}\text { Membuat cek list form } \\
\text { untuk keluar masuknya } \\
\text { form SKA. }\end{array}$ & $\begin{array}{l}\text { Melakukan pedampingan } \\
\text { berupa ISO } 900012015 \text { untuk } \\
\text { palayanan penerbitan SKA. }\end{array}$ \\
\hline & $\begin{array}{lr}\text { Belum } & \text { melakukan } \\
\text { uji } & \text { kopetensi } \\
\text { kepada } & \text { petugas } \\
\text { IPSKA. } & \\
\end{array}$ & $\begin{array}{l}\text { Melakukan uji kopetensi } \\
\text { secara berkala untuk } \\
\text { mengukur kopetensi } \\
\text { kinerja petugas IPSKA. }\end{array}$ & $\begin{array}{l}\text { Petugas IPSKA malakukan } \\
\text { pola pelayaan terintegrasi. }\end{array}$ \\
\hline DSS06 & $\begin{array}{lr}\text { Harga } & \text { satuan } \\
\text { barang } & \text { belum } \\
\text { mengacu } & \text { pada } \\
\text { peraturan } & \text { yang } \\
\text { berlaku. } & \end{array}$ & $\begin{array}{l}\text { Menetapkan harga satuan } \\
\text { barang dengan } \\
\text { melibatkan eksportir, } \\
\text { asosiasi dan pemerintah } \\
\text { yang mengacu pada } \\
\text { harga pasar. }\end{array}$ & $\begin{array}{l}\text { Dinas menetapkan standar } \\
\text { harga satuan barang komoditi } \\
\text { ekspor ditetapkan dengan } \\
\text { peraturan gubernur. }\end{array}$ \\
\hline
\end{tabular}

Rekomendasi eksisting mengacu pada PAM Using COBIT5 Toolkit-Self Assessment Templates pada domain proses TI dan mengambil rekomendasi tambahan dari COSO Internal Control Framework pada point yang mengacu pada kondisi eksisting layanan SKA serta mengambil saran dari peraturan pemerintah.

\section{Kesimpulan}

Kesimpulan yang didapat dari audit layanan surat keterangan asal untuk barang ekspor yaitu proses audit yang dilakukan dengan pemilihan domain proses TI, identifikasi tujuan bisnis, identifikasi tujuan TI, pengumpulan data kuesioner tingkat kepentingan, kuesioner capability level, perhitungan nilai kuesioner tingkat kepentingan dan capability level. Hasil dari domain proses TI yaitu terdapat 5 proses TI tertinggi yang terdiri dari EDM05, AP07, DSS02, DSS03, DSS06 yang mencapai status lagerly achieved pada masing-masing domain proses TI memiliki capaian tujuan yang berbeda. Saran dan perbaikan disesuaikan dengan standar PAM Using 
COBIT $5 \quad$ Toolkit-Self Assessment Templates dengan melihat expected capability yang lebih tinggi dari current capability yang didapat serta rekomendasi dari COSO Internal Control Framework sebagai saran dan perbaikan tambahan. Penelitian audit terkait dengan layanan instansi pemerintah dapat dikembangkan lebih lanjut mengunakan 37 proses TI pada Framework COBIT 5.

\section{Daftar Pustaka}

[1] Dinas Perdagangan dan Perindustrian Provinsi Bali, "EVALUASI PROGRAM EKSPOR NON MIGAS DAERAH BALI," pp. 20-38, 2017.

[2] Ni Kadek Rahayu Widya, I Putu Agung Bayupati and I Ketut Adi Purnawan, "Audit Capability EAM menggunakan COBIT 5 dan ISO 55002 pada Perusahaan Kelistrikan Negara," Jurnal IImiah Merpati Universitas Udayana, vol. 4, no. 3, pp. 195-204, 2016.

[3] I Ketut Adi Purnawan, Riza Afriza Islami, I Made Sukarsa, "Information Technology Governance Archetype in an Indonesian University," Telekomnika Indones. J. Electr. Eng., vol. 12, no. 7, p. 5636, 2014.

[4] I Wayan Prasada Bharaditya, I Made Sukarsa, and Putu Wira Buana, "Internal Control Improvement for Creating Good Governance," International Journal of Information Engineering and Electronic Business, vol. 9, no. 3, pp. 9-17, 2017.

[5] Altry David Purba, I Ketut Adi Purnawan, I Putu Agus Eka Pratama, "Audit Keamanan TI Menggunakan Standar ISO / IEC 27002 dengan COBIT 5," Jurnal Ilmiah Merpati Universitas Udayana, vol. 6, no. 3, pp. 148-158, 2018.

[6] Ni Putu Sri Merta Suryani, Gusti Made Arya Sasmita, and I Ketut Adi Purnawan, "Audit of accounting information system using COBIT 4.1 focus on deliver and support domain," Journal of Theoretical and Applied Information Technology, vol. 78, no. 3, pp. 456-463, 2015.

[7] I Ketut Adi Purnawan, "Pedoman Tata Kelola Teknologi Informasi Menggunakan IT Governance Design Framework (Cobit) Pada PT. X I," Lontar Komputer., vol. 6, no. 3, p. 200, 2015.

[8] I Putu Ade Ambara Putra, I Made Sukarsa, and I Putu Agung Bayupati, "Audit TI Kinerja Manajemen Pt . X Dengan Framework Cobit 4.1," Lontar Komputer., vol. 6, no. 1, pp. 13-24, 2015. 